\title{
TYPES OF HEADER, OPERATING SPEED, AND GEOMETRY OF COLLECTION FRAMES ON THE TOTAL LOSSES OF SOYBEAN HARVEST
}

\author{
Jorge W. Cortez ${ }^{*}$, Marina G. Syrioº ${ }^{2}$ Sonia A. Rodrigues ${ }^{2}$ \\ ${ }^{1 *}$ Corresponding author. Universidade Federal da Grande Dourados/ Dourados - MS, Brasil. \\ E-mail: jorgewcortez@gmail.com | ORCID ID: http://orcid.org/0000-0003-1120-719X
}

\section{KEYWORDS}

agricultural mechanization, control charts, Glycine max.

\begin{abstract}
Soybean has significant economic importance in Brazil despite high production costs, making it necessary to increase the efficiency of mechanized harvest through the reduction of losses. Thus, this study aimed to evaluate the total losses in the mechanized soybean harvest as a function of the combination of header types, operating speeds, and geometry of collection frames. The study was carried out in a commercial farm in a randomized block design arranged in a $2 \times 3 \times 3$ factorial with 10 replications, totaling 180 replications. The data were analyzed by descriptive statistics, analysis of variance, and quality control. The square frame can be used instead of the rectangular frame for the determination of the total losses. The increasing operating speed increased total losses in the auger header. On the other hand, the lowest losses at the highest operating speed were observed in the belt header. The harvester with belt header was more efficient when compared to that with auger header at the highest operating speed.
\end{abstract}

\section{INTRODUCTION}

Soybean cultivation has a high production cost due to the use of fertilizers, pesticides, machines, and seeds, which tends to intensify because of the dollar appreciation (Costa \& Santana, 2018). Thus, knowledge of operational quality in soybean harvesters provides useful information for management, aiming at obtaining the maximum yield of all available resources, with minimum expenses (Paixão et al., 2016).

In this context, mechanized harvesting is considered a complex stage in the production cycle of a crop (Bottega et al., 2014), and factors that directly influence the quality of the operation are internal mechanisms, adjustments, and machine working speed. In this sense, some authors have investigated the speed of soybean crop because it is a factor that affects losses (Carvalho Filho et al., 2005; Cunha \& Zandbergen 2007; Da Silva et al., 2013; Menezes et al., 2018) and observed that the highest losses occurred on the harvester header (Zandonadi et al., 2015). Thus, innovations and the use of belt headers can be an alternative to reduce losses associated with an operating speed that also provides lower loss rates. In fact, in harvester headers with a rubber belt, the plant is carried free of friction to the internal machine mechanisms, while an auger header generates higher friction (Cuochinski et al., 2018).
Knowing how harvest losses occur, as well as measuring them to determine which levels of losses are acceptable and practices necessary for correction is necessary to maintain them at low levels (Pishgar-Komleh et al., 2013). Harvest losses can be quantified using a $1-\mathrm{m}^{2}$ frame, although frame size has not affected the quantification and variability of losses in the mechanical harvesting of soybean (Loureiro Junior et al., 2014). However, studies on the use of collection frames have shown a significant difference in losses for different sampling areas using traditional (rectangular) shape. The study of areas and geometries of frames to evaluate losses is important because they have high values of the coefficient of variation, hindering the interpretation of results (Câmara et al., 2007).

Therefore, this study aimed to evaluate the total losses in the mechanized soybean harvest as a function of the combination of header types, operating speeds, and geometry of collection frames.

\section{MATERIAL AND METHODS}

This study was carried out in a commercial area destined to grain production and located in Dourados, at the geographical coordinates $22^{\circ} 11^{\prime} 49.88^{\prime \prime} \mathrm{S}$ and $54^{\circ} 52^{\prime} 33.91^{\prime \prime} \mathrm{W}$, with an altitude of $454 \mathrm{~m}$ and flat relief.

\footnotetext{
${ }^{2}$ Universidade Federal da Grande Dourados/ Dourados - MS, Brasil. 
This area has been cultivated with soybean in the summer and corn in the fall/ winter under the no-tillage system. The cultivar M6410 was grown with a row spacing of 0.50 $\mathrm{m}$ and 12 seeds per meter. The total losses were evaluated in 2018. The regional climate is CWa according to Köppen classification. The soil of the area is a dystroferric Red Latosol (Embrapa, 2013).

The experimental design was a randomized block design in a factorial arrangement, with two types of headers, three operating speeds, three geometries of collection frames for measuring losses, and 10 replications, totaling 180 plots. Each plot had $50 \mathrm{~m}$ in length and the same width as that of the harvester header $(10.6 \mathrm{~m})$, totaling $530 \mathrm{~m}^{2}$.

Harvester operating speeds were 5, 6, and $7 \mathrm{~km} \mathrm{~h}^{-1}$ for each plot. In this case, harvester started harvesting before the beginning of the plot to stabilize its speed. Two harvesters of the same brand and with a straw distributor were used (Table 1).

TABLE 1. Information of harvesters used in the experiment for headers $\mathrm{H} 1$ and $\mathrm{H} 2$.

\begin{tabular}{lcc}
\hline Harvester & H1 & H2 \\
\hline Age - years & 4 & 4 \\
Engine working time - hours & 1500 & 1350 \\
Power - kW (hp) & $239.2(325)$ & $278.2(378)$ \\
Header & Belt & Auger \\
Grain tank - L & 10570 & 11600 \\
Threshing system & Axial & Axial \\
Header width $-\mathrm{m}$ & 10.6 & 10.6 \\
Rotor diameter $-\mathrm{mm}$ & 762 & 750 \\
\hline
\end{tabular}

Three geometries of collection frames were used to determine the total losses. The first frame was developed by Mesquita \& Gaudêncio (1982) and considered as the standard geometry, which consists of a rectangular frame (RF) composed of string and iron, with a length equal to the harvester header width and width given as a function of the sampling area $\left(1 \mathrm{~m}^{2}\right)$, being positioned after harvester passage. The second frame presented a geometry with a circular shape (CF) composed of a metal ring with a diameter of $0.56 \mathrm{~m}$, corresponding to the area of $0.25 \mathrm{~m}^{2}$. Finally, the third frame had a square geometry (SF) with $0.5 \mathrm{~m}$ of side, corresponding to an area of $0.25 \mathrm{~m}^{2}$. The square and circular frames were placed transversely to the harvester position at four points after harvest, resulting in an area of $1 \mathrm{~m}^{2}$.

After determining the losses (collected grains), the samples were taken to the laboratory, where all impurity contained in the material was removed, and the weight of each sample was measured in a precision scale and dried in ovens, with values corrected to $13 \%$ moisture.

The data were analyzed through descriptive statistics, obtaining the mean, variance, standard deviation, minimum, maximum, coefficient of variation, skewness, kurtosis, and probability by the Ryan-Joiner test. Frequency distribution and box plot were also performed. Subsequently, the data were submitted to analysis of variance and, when significant, the Scott \& Knott test was applied at $5 \%$ probability for comparison of means.

The process stability was verified by control charts with centerlines (overall mean), and lower (LCL) and upper control limits (UCL) were calculated based on the standard deviation of variables (Trindade et al. 2000) (Equation 1, 2, and 3). In other words, mean minus three times the standard deviation for LCL and mean plus three times the standard deviation for UCL (Cassia et al., 2015; Arcoverde et al., 2016; Menezes et al., 2018).

$$
\begin{aligned}
& \mathrm{CL}=\mu \\
& \mathrm{UCL}=\mu+\sigma \\
& \mathrm{LCL}=\mu-\sigma
\end{aligned}
$$

Where,

$\mathrm{CL}$ is the centerline;

$\mu$ is the mean of the means of the subgroups;

UCL is the upper control limit;

$\sigma$ is the mean standard deviation, and

LCL is the lower control limit.

When the data extrapolated three times the standard deviation, represented by points above or below the LCL and UCL lines, respectively, it was considered as out of control. When the value of the standard deviation was negative, zero (SLL - specific lower limit) was used. The reference value for harvest losses of $60 \mathrm{~kg} \mathrm{ha}^{-1}$ (SCL specific control limit) was also added in the control charts.

\section{RESULTS AND DISCUSSION}

The data of harvest losses showed a distribution close to $61.60 \mathrm{~kg} \mathrm{ha}^{-1}$, with its break-even point represented on the distribution chart (Figure 1). Distribution is considered symmetric because the probability ( $p)$ is higher than or equal to 0.05 , with mode, mean, and median not differing from each other. The distribution curve presented a slight elongation to the right, which could be observed by the positive skewness coefficient (Table 2). The positive kurtosis coefficient presented a higher tapering in relation to the normal. The box-plot graph (Figure 1) showed the occurrence of discrepant points (outliers) that were part of the process, indicating the occurrence of special causes of variation, which may indicate an out of control process or with sampling errors. 

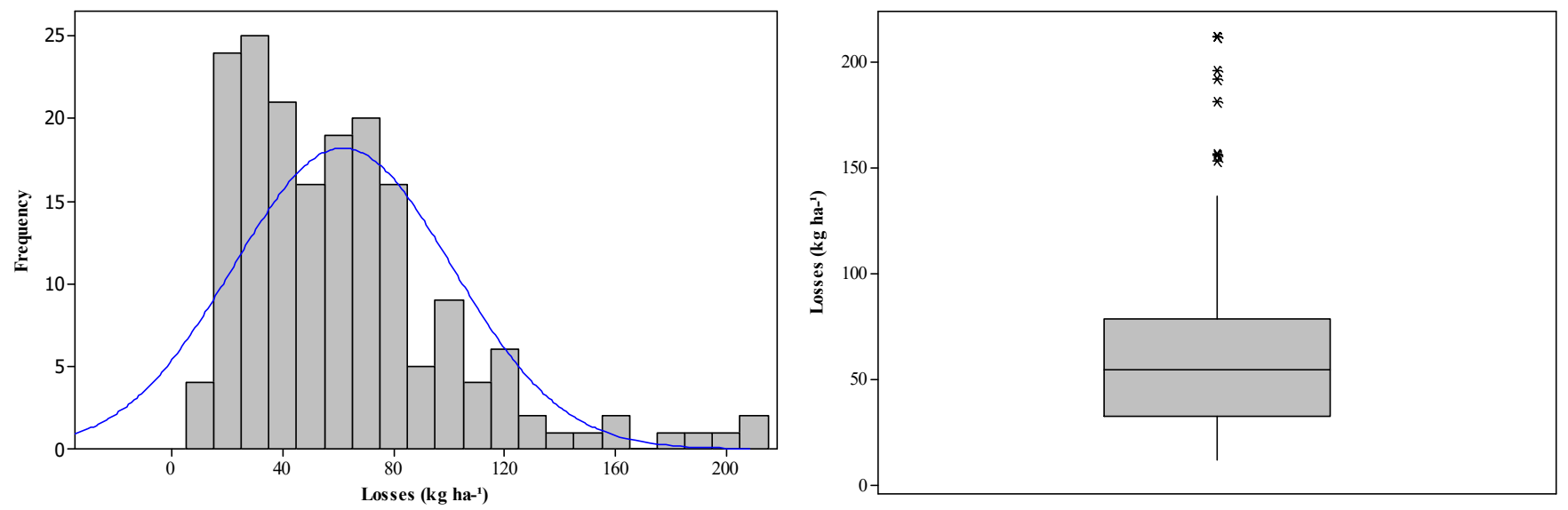

FIGURE 1. Frequency distribution and box-plot of the global data of harvest losses.

The data of harvest losses presented a high variability, which can be verified by the high values of amplitude, standard deviation, and coefficient of variation $(\mathrm{CV})$, which resulted in a separation between the mean and median (Table 2). These results showed that there was no uniformity in losses. A higher concentration of points was observed around values lower than the mean since skewness and kurtosis coefficients are positive.

The coefficient of variation $(64.03 \%)$ showed the variability of results, being considered very high. Other researchers have observed high values of coefficient of variation (Holtz \& Reis, 2013; Loureiro Júnior et al., 2014; Cassia et al., 2015; Menezes et al. 2018), suggesting the need for a classification of coefficient of variation that considers the specificities of the agricultural area due to the variability of soil, climate, and other conditions of crop cultivation. Because losses are not a uniform occurrence characteristic in the area, i.e., sometimes it appears, but sometimes it does not exist, causes the $\mathrm{CV}$ values to be high.

TABLE 2. Descriptive statistics of the data of total losses on soybean mechanized harvest.

\begin{tabular}{lc}
\hline Parameter & Losses $\left(\mathrm{kg} \mathrm{ha}^{-1}\right)$ \\
\hline Mean & 61.60 \\
SD & 39.45 \\
Variance & 1556.05 \\
CV $(\%)$ & 64.03 \\
Minimum & 11.99 \\
Median & 54.79 \\
Maximum & 211.82 \\
Amplitude & 199.83 \\
Skewness & 1.46 \\
Kurtosis & 2.65 \\
\hline
\end{tabular}

$* \mathrm{p} \geq 0.05$ normal, non-significant - symmetric data; $* * \mathrm{p}<0.05$ non-normal data, significant - asymmetric data. SD: standard deviation; $\mathrm{CV}$ : coefficient of variation.

A significant effect of the total losses in the soybean harvest was observed for the two types of header, three geometries of collection frames, and the interaction type of header versus operating speed (Table 3). Harvester speed alone did not affect the three studied speeds. Although there is no isolated effect of speed, higher losses usually occur when harvesters operate at speeds above 7 $\mathrm{km} \mathrm{h}^{-1}$ (Camolese et al., 2015). 
TABLE 3. Summary of the values of analysis of variance and test of means for losses in the soybean harvest.

\begin{tabular}{lc}
\hline Type of header (H) & Losses $\left(\mathrm{kg} \mathrm{ha}^{-1}\right)$ \\
\hline Belt (H1) & $72.71 \mathrm{a}$ \\
Auger (H2) & $50.48 \mathrm{~b}$ \\
\hline Operating speed (S) & $65.05 \mathrm{a}$ \\
$5.0 \mathrm{~km} \mathrm{~h}^{-1}$ & $64.78 \mathrm{a}$ \\
$6.0 \mathrm{~km} \mathrm{~h}^{-1}$ & $54.97 \mathrm{a}$ \\
$7.0 \mathrm{~km} \mathrm{~h}^{-1}$ & \\
\hline Geometry of collection (GC) & $73.92 \mathrm{a}$ \\
Rectangular (RF) & $63.02 \mathrm{a}$ \\
Square (SF) & $47.86 \mathrm{~b}$ \\
Circular (CF) & $19.99^{* *}$ \\
\hline F-teste & $1.78 \mathrm{~ns}$ \\
Header (H) & $9.24^{* *}$ \\
Speed (S) & $15.67^{* *}$ \\
Geometry of collection (GC) & $0.98^{\mathrm{ns}}$ \\
H x S & $1.15^{\mathrm{ns}}$ \\
H x GC & $0.83^{\mathrm{ns}}$ \\
V x GC & 54.79 \\
\hline H x S x GC & \\
\hline CV (\%) & \\
\hline
\end{tabular}

ns: not significant $(\mathrm{p}>0.05)$; *: significant $(\mathrm{p}<0.05)$;*: significant $(\mathrm{p}<0.01)$; CV: coefficient of variation. Means followed by the same lowercase letters in the column do not differ from each other by the Scott \& Knott test at $5 \%$ probability.

The harvester with belt header (H1) presented, in general, higher losses when compared to that with an auger header (H2) (Table 3). The circular frame (CF) showed the lowest losses. In addition, because the rectangular frame (RF) is a standard, the square frame (SF) could be used for determining losses, as it did not differ from RF (Table 3).

$\mathrm{H} 1$ presented no difference in harvest losses at 5.0 and $6.0 \mathrm{~km} \mathrm{~h}^{-1}$, differing only at $7.0 \mathrm{~km} \mathrm{~h}^{-1}$, in which it presented a lower loss (Table 4). However, the effect of the higher speed in $\mathrm{H} 2\left(7.0 \mathrm{~km} \mathrm{~h}^{-1}\right)$ provided the highest total loss. Therefore, the increased speed in $\mathrm{H} 2$ provided an increase in losses. It occurs in $\mathrm{H} 2$ probably because the reel, auger, and retractable fingers, together with the vibration caused by the cutter bar, threshed the pods that throw the seeds to the field (Holtz \& Reis, 2013). On the other hand, higher speeds led to lower losses in $\mathrm{H} 1$ due to the belt. It suggests that the use of a belt header allows working at higher speeds without reaching the critical level of losses $\left(60 \mathrm{~kg} \mathrm{ha}^{-1}\right)$.

TABLE 4. Summary of the slicing of the interaction of total losses $\left(\mathrm{kg} \mathrm{ha}^{-1}\right)$ for types of headers and operating speeds.

\begin{tabular}{lccc}
\hline Type of header $(\mathrm{H})$ & \multicolumn{3}{c}{ Operating speed $\left(\mathrm{S}-\mathrm{km} \mathrm{h}^{-1}\right)$} \\
& 5.0 & 6.0 & 7.0 \\
\hline H1 & $77.07 \mathrm{aA}$ & $84.82 \mathrm{aA}$ & $56.26 \mathrm{bB}$ \\
$\mathrm{H} 2$ & $32.87 \mathrm{bB}$ & $45.28 \mathrm{bB}$ & $73.30 \mathrm{aA}$ \\
\hline
\end{tabular}

\begin{tabular}{lccc}
\hline & & Sources of variation \\
\hline H x S - column & Factor H within S1 & Factor H within S2 & Factor H within S3 \\
Calculated F & $26.33^{* *}$ & $21.07^{* *}$ & $3.92^{* *}$ \\
\hline $\mathrm{S} \times \mathrm{H}-$ row & Factor S within H1 & Factor S within H2 & - \\
Calculated F & $5.88^{* *}$ & $11.56^{* *}$ & -
\end{tabular}

ns: not significant $(\mathrm{p}>0.05) ;{ }^{*}$ : significant $(\mathrm{p}<0.05) ; * *$ : significant $(\mathrm{p}<0.01)$. Means followed by the same lowercase letters in the column do not differ from each other by the Scott \& Knott test at 5\% probability. H1 - belt header; $\mathrm{H} 2$ - auger header; $\mathrm{S}$ - operating speed. 
The lower losses in belt header (H1) was observed only at the highest speed. Similarly, Menezes et al. (2018) evaluated the quality of mechanized soybean harvesting in Rondônia using harvesters with different headers and operating speeds through statistical process control and concluded that the best quality of the harvesting process was obtained with the belt header, with lower mean losses.

Analyzing the behavior of each speed individually (Table 4), H2 (auger header) showed a lower loss at 5.0 and $6.0 \mathrm{~km} \mathrm{~h}^{-1}$ when compared to $\mathrm{H} 1$ (belt header). However, $\mathrm{H} 1$ presented the lowest loss at a speed of 7.0 $\mathrm{km} \mathrm{h}^{-1}$. Probably, the increased speed and higher flow of material into the belt header allowed it to transport the mass to the feed channel with less friction, resulting in smaller losses. On the other hand, the auger header was efficient only at lower speeds, when mass flow is lower.

The analysis of harvest losses through quality techniques derived from industrial processes is important to monitor the harvesting process in a continuous way. The statistical quality control (SQC) analyzes the interval of three times the standard deviation, for more or less, in relation to the mean of the data. The permanence of values of total loss within these limits (three times the standard deviation) indicates process stability. Thus, control charts for total soybean losses showed extrapolations of the upper limits (three times the standard deviation) for both types of headers, characterizing the process as unstable, i.e., out of control (Figure 2). It explains the high CV values since the occurrence of losses varies greatly as the harvester moves in the field. However, the harvester with the $\mathrm{H} 2$ header showed the lowest variability, which can be verified by the lower interval between the lower (LCL) and upper control limits (UCL). In addition, the lowest mean loss was observed in $\mathrm{H} 2$, with a value below the critical limit of 60 $\mathrm{kg} \mathrm{ha}{ }^{-1}$, as suggested by Silveira \& Conte (2013). Zandonadi et al. (2015) evaluated the total losses in municipalities of northern Mato Grosso and observed that harvesters under adequate working conditions presented a mean total loss of $57 \mathrm{~kg} \mathrm{ha}^{-1}$, which is below the critical limit, and harvesters with axial system favored lower losses.

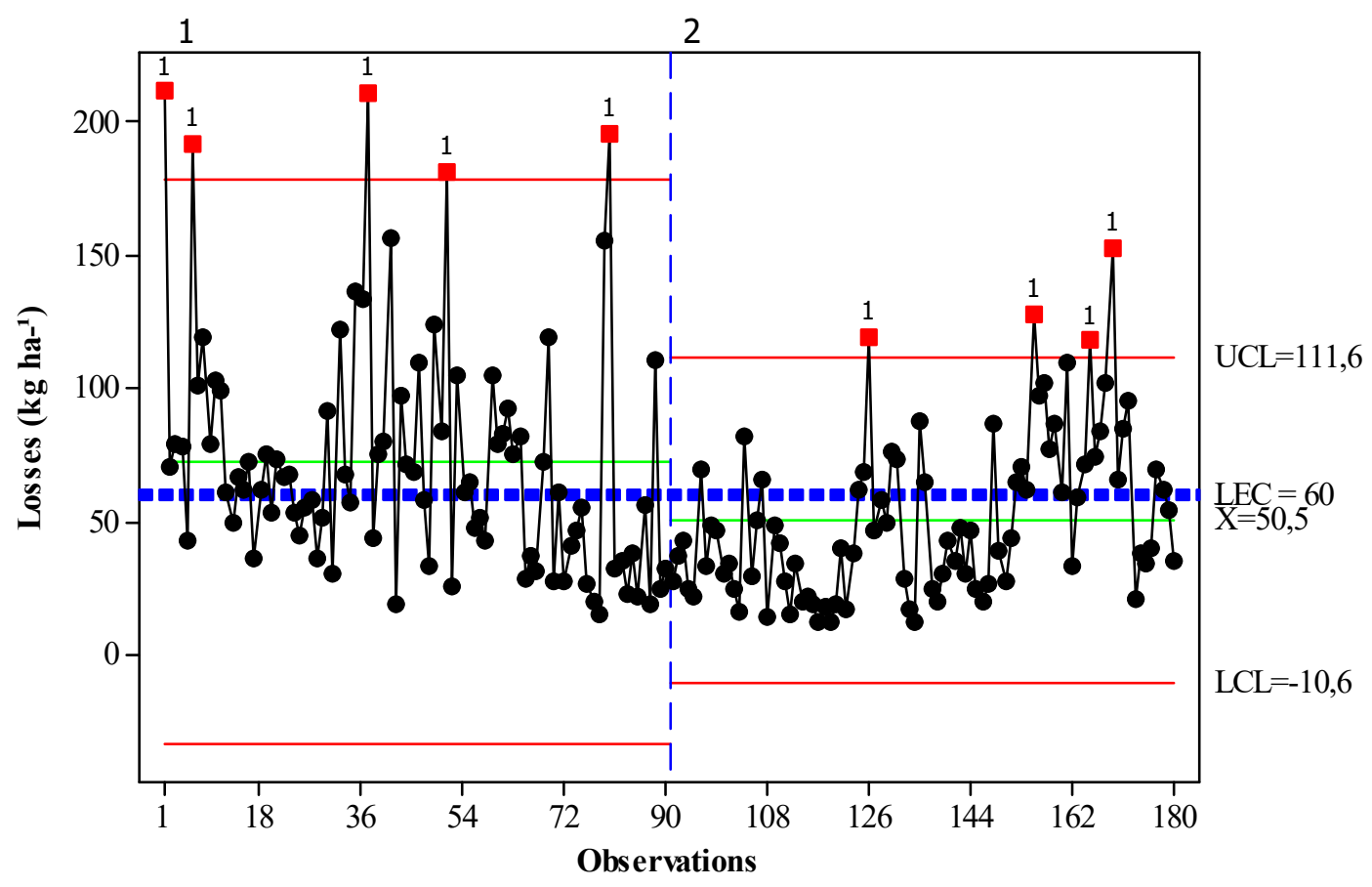

FIGURE 2. Control charts for losses considering the types of harvesters (1 - H1 and 2 - H2). UCL - upper control limit; LCL - lower control limit; SCL - specific control limit; X - mean $\left(\mathrm{kg} \mathrm{ha}^{-1}\right)$.

An extrapolation of the upper limit was observed at the three operating speeds, i.e., the process was unstable or out of control (Figure 3), with points above three times the standard deviation. The lower speed $\left(5.0 \mathrm{~km} \mathrm{~h}^{-1}\right)$ provided a lower mean variation of total losses but was close to the other speeds. Thus, lower speeds should be used to maintain higher regularity of losses. However, Oliveira et al. (2014) evaluated losses in corn harvest and did not find the effect of speed and grain moisture on losses. 


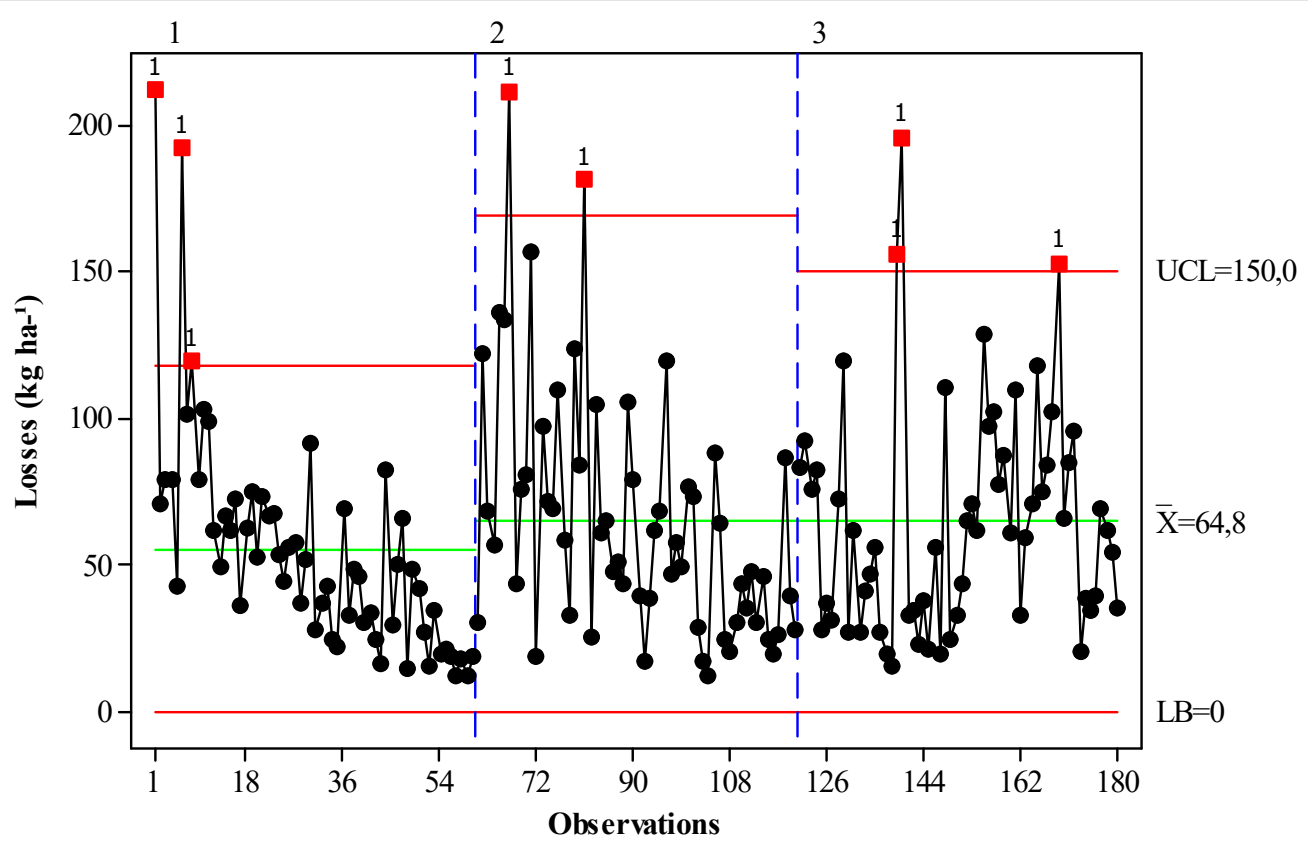

FIGURE 3. Control charts for total losses considering the speeds $\left(1-5.0 \mathrm{~km} \mathrm{~h}^{-1}, 2-6.0 \mathrm{~km} \mathrm{~h}^{-1}\right.$, and $\left.3-7.0 \mathrm{~km} \mathrm{~h}^{-1}\right)$. UCL upper control limit; LB - specific lower limit; X - mean $\left(\mathrm{kg} \mathrm{ha}^{-1}\right)$.

Control charts of the total losses for geometries of collection frames (Figure 4) showed that SF was the frame that most resembled RF. In addition, the data variability was slightly lower with SF, which is an indication that it can be used to quantify the total losses. However, CF did not show this same behavior, i.e., its results do not serve as an indication to measure the total losses in the field since they underestimate losses (Figure 4).

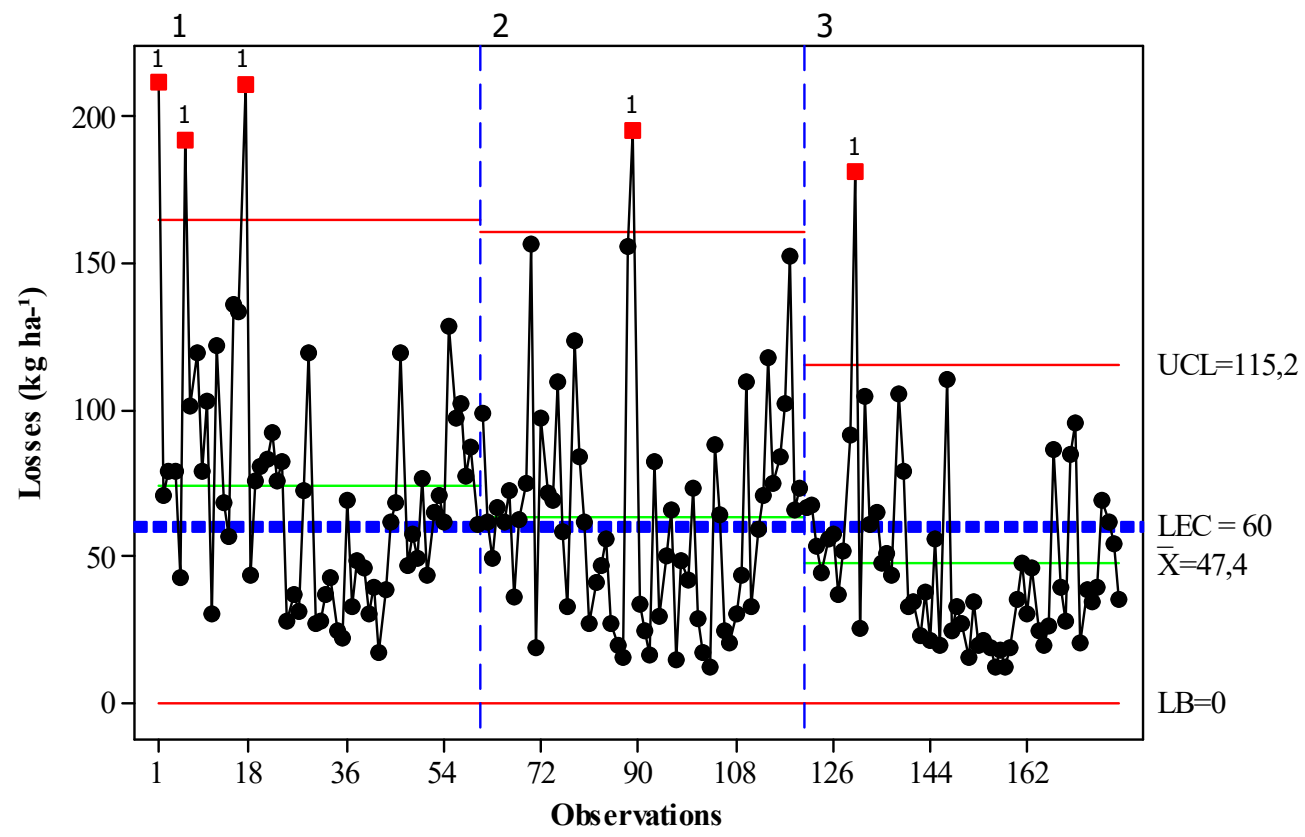

FIGURE 4. Control charts for total losses considering the geometries of collection frames $(1$ - rectangular frame, RF, 2 square frame, SF, and 3 - circular frame, CF). UCL - upper control limit; LB - specific lower limit; LEC - specific control limit; $\mathrm{X}$ - mean $\left(\mathrm{kg} \mathrm{ha}^{-1}\right)$.

The control chart for total losses considering the types of headers at all speeds (Figure 5) had a stable behavior only to the harvester with belt header (H1) at a working speed of $6.0 \mathrm{~km} \mathrm{~h}^{-1}$, but its losses presented the highest values of variation when compared to all other treatments. The harvester with auger header (H2) presented a lower variation of losses when compared to $\mathrm{H} 1$, regardless of the working speed. 


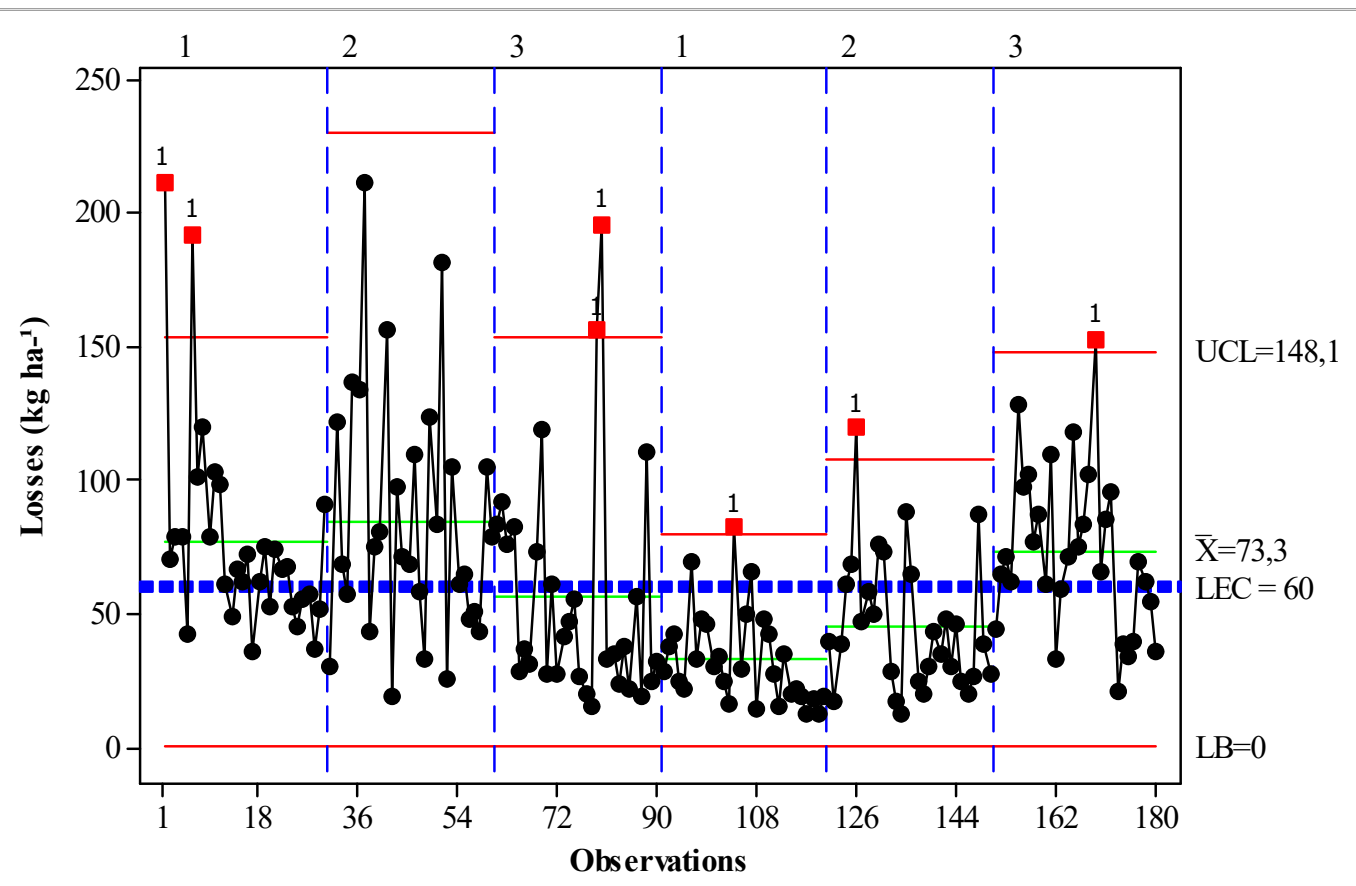

FIGURE 5. Control charts for total losses considering the harvesters ( 1 - H1S1, 2 - H1S2, $3-\mathrm{H} 1 \mathrm{~S} 3,1-\mathrm{H} 2 \mathrm{~S} 1,2$ - H2S2, 3 $\mathrm{H} 2 \mathrm{~S} 3$, respectively), where $\mathrm{S} 1-5.0 \mathrm{~km} \mathrm{~h}^{-1}, \mathrm{~S} 2-6.0 \mathrm{~km} \mathrm{~h}^{-1}, \mathrm{~S} 3-7.0 \mathrm{~km} \mathrm{~h}^{-1}, \mathrm{H} 1$ - belt header, and H2 - auger header. UCL upper control limit; LB - specific lower limit; LEC - specific control limit; X - mean $\left(\mathrm{kg} \mathrm{ha}^{-1}\right)$.

In general, comparing all the treatments (Figure 5), $\mathrm{H} 2$ at a low working speed $\left(5.0\right.$ and $\left.6.0 \mathrm{~km} \mathrm{~h}^{-1}\right)$ presented the best result since it had lower soybean, with most values below the specific limit of $60 \mathrm{~kg} \mathrm{ha}{ }^{-1}$. In addition, an increase in total losses was observed as speed increased in $\mathrm{H} 2$, similar to the behavior observed by Machado et al. (2012).

The values of H1 (belt header) when subjected to a speed of $7.0 \mathrm{~km} \mathrm{~h}^{-1}$ remained below the tolerable limit for total losses of soybean grains, according to Cunha \& Zandbergen (2007). On the other hand, H2 presented most of the total losses above the tolerated limit when submitted to the same speed $\left(7.0 \mathrm{~km} \mathrm{~h}^{-1}\right)$. In contrast, Cuochinski et al. (2018) did not find any difference in the total losses when evaluating harvesters with belt and auger headers in two plots, which was attributed to the high grain and mass moistures.

The harvester with auger header presented increasing total losses of soybean as speed increased, while the harvester with belt header had the highest losses at a working speed of $6.0 \mathrm{~km} \mathrm{~h}^{-1}$ and the lowest losses at $7.0 \mathrm{~km} \mathrm{~h}^{-1}$. Therefore, losses are not due to machine age but to the lack of adequate regulation and training of operators (Pinheiro Neto, 2004), besides the increment of new technologies, which may explain the discrepant data found in this study.

\section{CONCLUSIONS}

The square frame can be used instead of the rectangular frame for determining the total losses.

The increasing operating speed increased total losses in the auger header. Harvesters with auger headers must have an operating speed of up to $6.0 \mathrm{~km} \mathrm{~h}^{-1}$.

The lowest losses in the harvester with belt header were observed only at the highest operating speed.

\section{ACKNOWLEDGMENTS}

To Capes for granting the doctoral scholarship to the third author.

\section{REFERENCES}

Arcoverde SNS, de Souza CMA, Cortez JW, Guazina RA, Maciak PAG (2016) Qualidade do processo de semeadura da cultura do milho de segunda safra. Revista Engenharia na Agricultura 24(5):383-392.

Bottega EL, Souza CMA, Rafull LZL, Queiroz DM (2014) Avaliação de uma colhedora e da qualidade de sementes de forragem colhidas por varredura. Revista Ciências Exatas e da Terra e Ciências Agrárias 9(1):10-20.

Da Silva RP, Da Silva BM, Barrozo LM, Salum JD, Rosa, MS, Gomes, DP (2013) Perdas qualitativas na colheita mecanizada de sementes de soja. Semina: Ciências Agrárias 34(2):477-484.

Câmara FT, Silva RP, Lopes A, Furlani CEA, Grotta DCC, Reis GN (2007) Influência da área de amostragem na determinação de perdas totais na colheita de soja. Ciência e Agrotecnologia 31(3):909-913.

Camolese HS, Baio FH R, Alves C Z (2015) Perdas quantitativas e qualitativas de colhedoras com trilha radial e axial em função da umidade do grão. Revista Brasileira de Engenharia de Biossistemas 9(1):21-29.

Carvalho Filho A, Cortez JW, Silva RP Da, Zago M de S (2005) Perdas na colheita mecanizada da soja no triângulo mineiro. Revista Nucleus 3(1):1-6.

Cassia MT, Voltarelli M A, da Silva RP, Zerbato C, Lima PH (2015) Monitoramento da operação de colheita mecanizada de sementes de soja. Revista Brasileira de Engenharia Agrícola e Ambiental 19(12):1209-1214. 
Costa NL, Santana A (2018) Análise do Mercado da Soja: Aspectos Conjunturais da Formação do Preço Pago ao Produtor Brasileiro. Revista Plantio Direto 28:20-39.

Cunha JPAR, Zandbergen HP (2007) Perdas na colheita mecanizada da soja na região do Triangulo Mineiro e Alto Paranaíba. Bioscience Journal 23(4):61-66.

Cuochinski RMs, Fernandes CM, Lima Junior AF, Moreira JM, Silva AP, Carvalho LR, Rosa JQS (2018) Perdas na colheita mecanizada de soja utilizando diferentes mecanismos na plataforma de corte. Pubvet 12(7):1-5.

Embrapa - Empresa Brasileira de Pesquisa Agropecuária (2013) Sistema brasileiro de classificação de solos. 3.ed. Brasília, Embrapa, 353p.

Holtz V, Reis EF dos (2013) Perdas na colheita mecanizada de soja: Uma análise quantitativa e qualitativa. Revista Ceres 60(3):347-353.

Loureiro Júnior AM, Silva RP da, Cassia MT, Compagnon AM, Voltarelli MA (2014) Influence of the sample area in the variability of losses in the mechanical harvesting of soybeans. Engenharia Agrícola 34(1):76-85.

Machado TA, Santos FL, Cunha JPB, da Cunha DA, Coelho LM (2012) Perdas na plataforma de corte de uma colhedora combinada de grãos na colheita de soja. Revista Engenharia na Agricultura 20(6):537-543.

Menezes PCD, Silva R PD, Carneiro FM, Girio LADS, Oliveira MFD, Voltarelli MA (2018) Can combine headers and travel speeds affect the quality of soybean harvesting operations? Revista Brasileira de Engenharia Agrícola e Ambiental 22(10):732-738.
Mesquita CM, Gaudêncio CA (1982) Medidor de perdas na colheita de soja e trigo. Londrina, Embrapa Soja, 8p.

Oliveira TC, Figueiredo ZN, Favare HG, Troui JG, Silva RP (2014) Perdas quantitativas na colheita mecanizada de milho safrinha na região norte de mato grosso. Agrarian Academy 1(02):141-149.

Paixão CSS, dos Santos AF, Voltarelli MA, da Silva RP, Carneiro FM (2016) Eficiência de tempos e qualidade da colheita mecanizada de soja em função da geometria dos talhões. Engenharia Agrícola 37(1):106-115.

Pinheiro Neto R (2004) Minimizando as Perdas. Revista Plantio Direto 33:18-21.

Pishgar Komleh SH, Keyhani A, Mostofi Sarkari MR, Jafari A (2013) Assessment and determination of seed corn combine harvesting losses and energy consumption. Agriculture 54:12631-12637.

Silveira JM, Conte O (2013) Determinação de perdas na colheita mecanizada de soja: copo medidor da Embrapa. Londrina, Embrapa Soja, 17p.

Trindade C, Rezende JLP, Jacovine LAG, Sartório ML (2000) Ferramentas da qualidade: aplicação na atividade florestal. Viçosa, Universidade Federal de Viçosa, 124p.

Zandonadi RS, Ruffato S, Figueiredo ZN (2015) Perdas na colheita mecanizada de soja na região Médio-Norte de Mato Grosso: Safra 2012/2013. Nativa 3(01):64-66. 